\title{
SPATIOTEMPORAL DISTRIBUTION PATTERNS OF BENTHIC MACROINVERTEBRATE FUNCTIONAL FEEDING GROUPS IN THE BLYDE RIVER, SOUTH AFRICA
}

\author{
AdDo-BEDIAKo, A. \\ Department of Biodiversity, University of Limpopo, Private Bag X1106, Sovenga 0727, South Africa \\ (e-mail: abe.addo-bediako@ul.ac.za; phone: +27-15-268-3145; ORCID:0000-0002-5055-8315)
}

(Received $5^{\text {th }}$ Dec 2020; accepted $3^{\text {rd }}$ Mar 2021)

\begin{abstract}
The impacts of land use changes and differences in seasonality on benthic macroinvertebrate composition were evaluated in the Blyde River of the Olifants River. The highest taxon richness and abundance of macroinvertebrates were at S6 and S5 respectively. These could be due to the high habitat heterogeneity and availability of food resources. The abundance and richness of taxa were greater in winter and spring respectively and both were lower in summer. The composition of macroinvertebrate community and distribution of functional feeding groups (FFG) differed significantly among sites. Collector-gatherers and collector-filterers were the most abundant groups recorded. The least abundant group was the shredders. The low abundance of shredders could be attributed to the enhanced microbial activity replacing shredder activity at high temperatures. The relative abundance and richness of the functional feeding groups did not conform fully to the River Continuum Concept (RCC). This could be due to human activities in the catchment that may be causing a change in the habitat and water quality at various sites. The results suggest that policies governing changes in land use is necessary to conserve the river and the macroinvertebrate community.
\end{abstract}

Keywords: bioindicators, distribution, land use, river continuum concept, water quality

\section{Introduction}

Many river systems are continuously undergoing degradation throughout their course of flow due to pollution from various anthropogenic activities, such as mining, agriculture and expanding human settlements (Zhang et al., 2015; Mimba et al., 2018; Chen et al., 2019). Anthropogenic effluents from the catchment of rivers are causing the deterioration of river systems and affecting the biotic communities (Jooste et al., 2015; Jun et al., 2016; Addo-Bediako et al., 2018). Assessment of the ecological status of rivers is a vital in managing river ecosystems in the world.

Biological monitoring is one of the methods used to determine the effects of anthropogenic activities on water quality of rivers and it is very useful to obtain their ecological information (Merritt et al., 2017). Macroinvertebrates are widely used as bioindicators of aquatic ecosystems because they are sensitive to changes in physical and chemical variables of ecosystems and reflect environmental conditions (Rosenberg and Resh, 1993). Benthic macroinvertebrates, for example, provide a more accurate understanding of changes in aquatic conditions when compared to chemical and microbiological data, which rather present short-term fluctuation (Ghasemi and Kamali, 2014). Macroinvertebrates respond to anthropogenic disturbance and natural changes in their habitats by changing their community structure. They serve as a major components of aquatic food webs that link organic matter and nutrient resources (e.g., leaf litter, algae and detritus) with higher trophic levels ( $\mathrm{Li}$ et al., 2010). Furthermore, macroinvertebrates are made up of many species from different taxonomic levels with a wide range of trophic levels and pollution tolerances (Qu et al., 2013). 
Benthic macroinvertebrates have a high diversity and a differentiated functional form according to the given physicochemical conditions of rivers and therefore respond to changes in the various environmental variables (Jun et al., 2016; Kim et al., 2016). Hence, there has been an increase in the use of functional feeding group (FFG) of benthic macroinvertebrate assemblages to assess environments ( $\mathrm{Fu}$ et al., 2016). The FFG approach is considered to be more appropriate and rapid for characterizing ecosystem conditions, compared with taxonomical approach (Cummins et al., 2005; Mishra and Nautiyal, 2013; Cummins, 2016). It is used to assess the effect of land use disturbances on river functioning (De Castro et al., 2016), thus FFG provides a further perspective together with other community indices to ensure a better understanding of the relationship between habitat and aquatic fauna (Townsend et al., 1997). The River Continuum Concept (RCC) is widely used to explain the functioning of lotic ecosystems and predicts how relative FFG abundance change along a river gradient (Vennote et al., 1980). The RCC proposes that community structure should shift from an allochthonous in the headwater to an autochthonous in the downstream of the river, as the river widens and algal production increases (Allan and Castillo, 2007). Functional composition is therefore necessary for management actions to enhance ecosystem functioning (Ferreira et al., 2012). This approach is seen to provide more accurate assessment of water quality and ecological integrity of rivers, which indeed could be used for conservation and restoration strategies in managing river ecosystems (Príncipe et al., 2010).

The effect of changes in environmental variability on functional feeding groups of macroinvertebrate communities has scarcely been explored in South African rivers. Most of the studies on macroinvertebrate functional composition to land-use changes have been done in the temperate regions. However, land-use impacts are regionally specific due to the strong influence of cultural, historical, climatic and landscape settings on indicator-disturbance relationships (Zhang et al., 2012). Information regarding the structure and functioning of macroinvertebrates in the Blyde River is rare. The Blyde River was selected for the study because it is one of the few rivers in the Olifants River System known to have good water quality despite the increasing number of anthropogenic activities in the catchment (Ashton and Dabrowski, 2011). The objective of this study was to assess the spatial and temporal structure of aquatic macroinvertebrate community using the FFG approach in the Blyde River and to determine if the macroinvertebrate community structure corresponds to the River Continuum Concept (RCC). It is envisaged that the results of the study would be used to design proper conservation tool in the river system.

\section{Materials and methods}

\section{Study area}

The Blyde River rises on the western slopes of the north-south trending Drakensberg Mountains and flows northwards towards the escarpment edge where it is dammed. From the dam, the Blyde River cascades down a steep series of rapids to its lower reaches, where the river again flows northwards to join the Olifants River at the town of Hoedspruit in Limpopo Province (DWAF, 2004). The Blyde River sub-catchment is approximately $2000 \mathrm{~km}^{2}$ in size. Geologically, the northern part of the sub-catchment is made up of crystalline gneissic and granitic rocks of the Basement Complex, underlying the catchment (DWAF, 2004). The sub-catchment lies partly on the escarpment and, as 
a result, experiences higher rainfall considerably than the other sub-catchments in the Olifants River Basin, with mean annual precipitation sometimes exceeding $1000 \mathrm{~mm}$ (DWAF, 2004). During the last decade, there has been an increase in human activities in the area, especially agriculture, which are likely to cause environmental pollution in the freshwater systems. Seven sampling sites were selected along the river (Fig. 1). S1

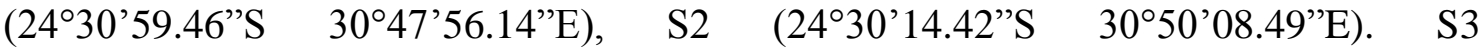

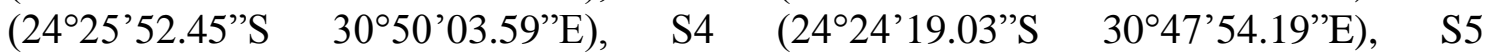

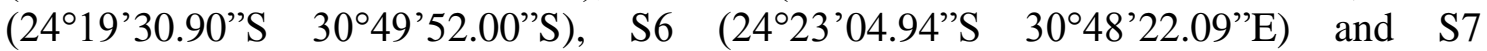
$\left(24^{\circ} 15^{\prime} 30.38^{\prime \prime} \mathrm{S} 30^{\circ} 50^{\prime} 13.22^{\prime \prime} \mathrm{E}\right)$. The detailed description of the sampling sites is given in Table 1.

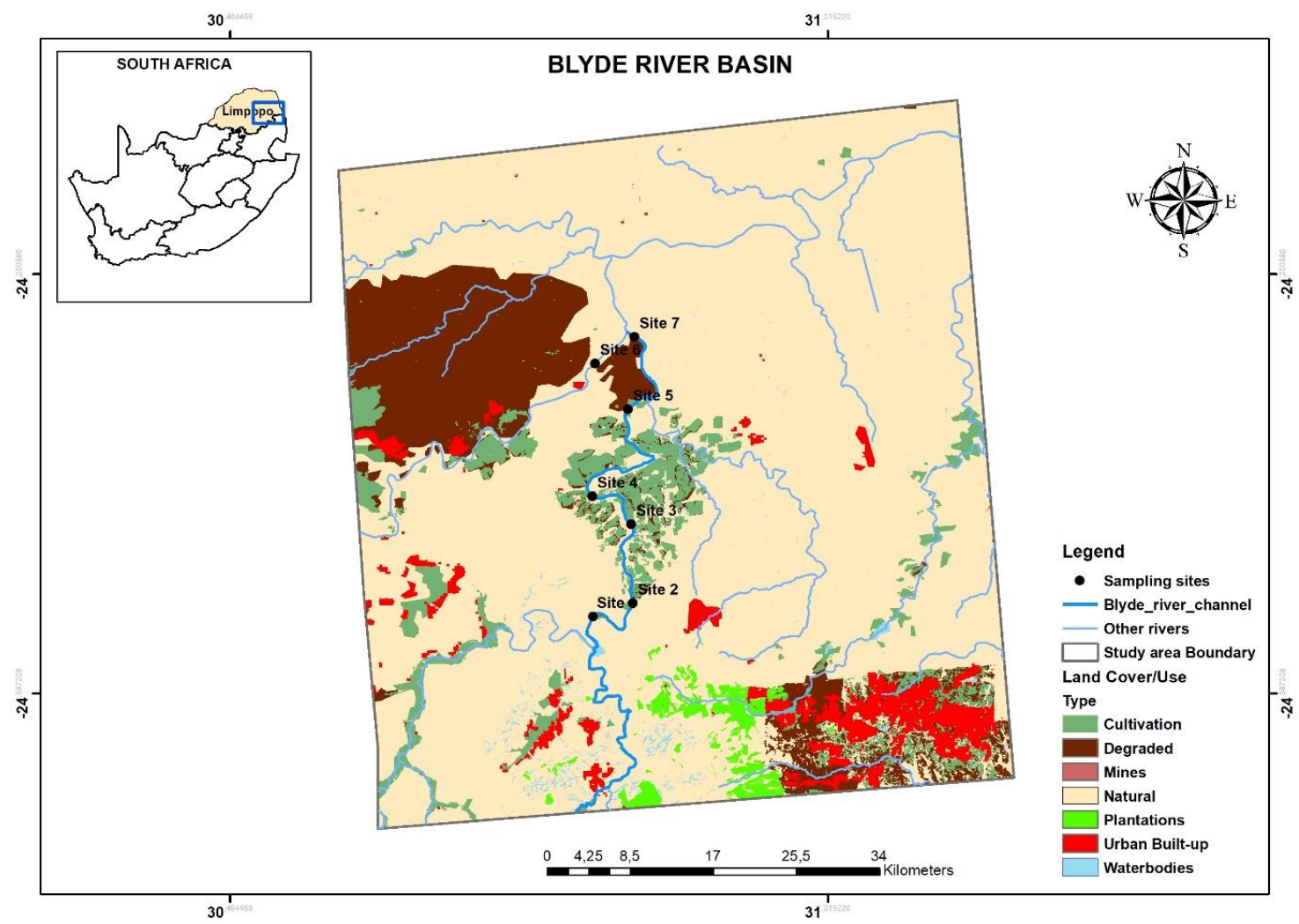

Figure 1. Map of the study area, showing the locations of the seven sampling sites of the Blyde River

\section{Physicochemical parameters}

The study was carried out in January (summer), April (autumn), July (winter) and November (spring), 2018. Water samples were collected in $500 \mathrm{ml}$ polyethylene bottles (acid pre-treated) and stored in a cooler box in the field using ice packs before being transported to the laboratory. Four water samples were collected from each site during the study. In the laboratory, the samples were stored at $4{ }^{\circ} \mathrm{C}$ prior to analyses. Three readings of environmental variables, such as $\mathrm{pH}$, water temperature, dissolved oxygen, (DO), total dissolved solids (TDS) and electrical conductivity (EC) were recorded at each site using a YSI Model 554 Data logger. Laboratory measurements were conducted to determine the nutrients $\left(\mathrm{NH}_{4}, \mathrm{NO}_{2}, \mathrm{NO}_{3}\right.$ and $\left.\mathrm{PO}_{4}\right)$ and turbidity, using a spectrophotometer (Merck Pharo 100 Spectroquant ${ }^{\mathrm{TM}}$ ) with Merck cell test kits in the Biodiversity Water Laboratory, University of Limpopo. Percentage riparian vegetation 
cover was visually estimated at each sampling station over a 20 to $30 \mathrm{~m}$ riparian width. The following parameters were also measured; Stream width, the distance from bank to bank at a transect representative of the stream channel using a measuring tape; (ii) water depth, the vertical distance from the water surface to stream bottom using a meter ruler and (iii) current velocity at riffles or gliding runs using a flow meter.

Table 1. Description of the study sites of the Blyde River

\begin{tabular}{|c|c|c|c|c|c|c|c|c|c|}
\hline \multirow{2}{*}{ Sites } & \multirow{2}{*}{\begin{tabular}{c|}
$\begin{array}{c}\text { Watershed } \\
\text { features }\end{array}$ \\
$\begin{array}{c}\text { Nature and land } \\
\text { use }\end{array}$ \\
\end{tabular}} & \multirow{2}{*}{\begin{tabular}{|c|}
$\begin{array}{c}\text { Riparian } \\
\text { vegetation }\end{array}$ \\
Structure
\end{tabular}} & \multirow{2}{*}{$\begin{array}{c}\begin{array}{c}\text { In-stream } \\
\text { features }\end{array} \\
\begin{array}{c}\text { Canopy } \\
\text { cover }\end{array} \\
\end{array}$} & \multirow{2}{*}{$\begin{array}{c}\text { Mean } \\
\text { width }(m)\end{array}$} & \multirow{2}{*}{$\begin{array}{l}\text { Depth } \\
\text { (m) }\end{array}$} & \multirow{2}{*}{ Type } & \multicolumn{3}{|c|}{ Substratum } \\
\hline & & & & & & & Cobble/pebble & Sand & Silt/clay \\
\hline S1 & Lodge/residential & $\begin{array}{c}\text { Trees, shrubs, } \\
\text { reeds }\end{array}$ & $\begin{array}{c}\text { Moderate } \\
(60 \%)\end{array}$ & 18 & 0.28 & Riffle & $50 \%$ & $30 \%$ & $20 \%$ \\
\hline $\mathrm{S} 2$ & Agriculture & $\begin{array}{c}\text { Trees, reeds, } \\
\text { grass }\end{array}$ & $\begin{array}{l}\text { Slight } \\
(40 \%)\end{array}$ & 9.5 & 0.33 & Riffle & $30 \%$ & $50 \%$ & $20 \%$ \\
\hline S3 & Agriculture & $\begin{array}{c}\text { Trees, shrubs, } \\
\text { reeds }\end{array}$ & $\begin{array}{c}\text { Moderate } \\
(50 \%)\end{array}$ & 9 & 0.35 & Riffle & $50 \%$ & $30 \%$ & $20 \%$ \\
\hline S4 & Industrial area & $\begin{array}{c}\text { Trees, shrubs, } \\
\text { grass }\end{array}$ & $\begin{array}{l}\text { Slight } \\
(40 \%)\end{array}$ & 16 & 0.32 & Riffle & $45 \%$ & $35 \%$ & $20 \%$ \\
\hline S5 & Agriculture & $\begin{array}{c}\text { Trees, shrubs, } \\
\text { reeds }\end{array}$ & $\begin{array}{c}\text { Moderate } \\
(60 \%)\end{array}$ & 26 & 0.25 & Riffle, pool & $40 \%$ & $30 \%$ & $30 \%$ \\
\hline S6 & Nature reserve & $\begin{array}{c}\text { Trees, reeds, } \\
\text { shrubs }\end{array}$ & $\begin{array}{c}\text { Moderate } \\
(65 \%)\end{array}$ & 17.5 & 0.20 & Riffle & $50 \%$ & $25 \%$ & $25 \%$ \\
\hline S7 & $\begin{array}{l}\text { Nature reserve, } \\
\text { confluence with } \\
\text { the Olifants River }\end{array}$ & Grass, shrubs & None & 8 & 0.33 & Riffle & $40 \%$ & $40 \%$ & $20 \%$ \\
\hline
\end{tabular}

\section{Sampling of macroinvertebrates}

Benthic macroinvertebrate samples were collected at the seven sites of the Blyde River during the four seasons. The samples were collected within a $100-\mathrm{m}$ stretch of the study sites, with substrate of biotopes consisting mainly of mud, sand, gravel or stones. Samples were collected using a $30 \mathrm{~cm}$ by $30 \mathrm{~cm}$ sampling net with a $500 \mu \mathrm{m}$ mesh size. Benthic macroinvertebrates were collected using the kick sampling method described by Dickens and Graham (2002), whereby the substrate was disturbed by kicking to free macroinvertebrates. Each site was sampled three times for benthic macroinvertebrates. The macroinvertebrates were then separated from organic and mineral matter, counted and identified to family level using Gerber and Gabriel's field guide manual (2002). Where specimens could not be identified in the field, the samples were preserved in $70 \%$ ethanol and transported to the laboratory for further identification, with the aid of a stereomicroscope (Leica EZ4) and magnifying glass. Macroinvertebrates were further classified into functional feeding groups using the key of Cummins et al. (2005), which classified the aquatic macroinvertebrates into the following functional feeding groups: Shredders (Sh) macroinvertebrates that chew conditioned litter or live vascular plant tissue (coarse particulate organic matter); Gathering-collectors (GC), that acquire fine particulate organic matter from interstices in the bottom sediments; Filtering-collectors (FC), that capture fine particulate organic matter from the water column using silken nets and filtering fans; Scrapers (Sc), which feed on algae attached on stable surfaces; Predators $(\mathrm{P})$, which feed on living prey (Table 2). Abundance of macroinvertebrate FFGs in each site and season were then calculated. 
Table 2. Functional group characterization and food resources (from Merritt and Cummis, 1996)

\begin{tabular}{c|c|c|c}
\hline $\begin{array}{c}\text { Type of } \\
\text { FFG }\end{array}$ & Particle size feeding mechanism & Dominant food resources & $\begin{array}{c}\text { Range of particle } \\
\text { size of food (mm) }\end{array}$ \\
\hline Shredders & $\begin{array}{c}\text { Chew conditioned litter or live } \\
\text { vascular plants tissue, or gouge } \\
\text { wood }\end{array}$ & $\begin{array}{c}\text { CPOM - decomposing (or living } \\
\text { hydrophytes) vascular plants }\end{array}$ & $>1.0$ \\
\hline $\begin{array}{c}\text { Filtering } \\
\text { collectors }\end{array}$ & $\begin{array}{c}\text { Suspension feeders-filter particles } \\
\text { from water column }\end{array}$ & $\begin{array}{c}\text { FPOM-decomposing detrital } \\
\text { particles; algae, bacteria and feces }\end{array}$ & $0.01-1.0$ \\
\hline $\begin{array}{c}\text { Gathering } \\
\text { collectors }\end{array}$ & $\begin{array}{c}\text { Deposits feeders-ingest sediments } \\
\text { or gather loose particles in } \\
\text { depositional areas }\end{array}$ & $\begin{array}{c}\text { FPOM- decomposing detrital } \\
\text { particles; algae, bacteria and feces }\end{array}$ & $0.05-1.0$ \\
\hline Scraper & $\begin{array}{c}\text { Graze rock and wood surfaces or } \\
\text { stems of rooted aquatic plants }\end{array}$ & $\begin{array}{c}\text { Periphyton attached non- } \\
\text { filamentous algae and associated } \\
\text { detritus, microflora, fauna and } \\
\text { feces }\end{array}$ & $0.01-1.0$ \\
\hline Predators & $\begin{array}{c}\text { Capture and engulf prey or tissue, } \\
\text { ingest body fluids }\end{array}$ & Prey- living animal & $>0.5$ \\
\hline
\end{tabular}

FFG - Functional Feeding Group, CPOM - Coarse Particulate Organic Matter, FOPM - Fine Particulate Organic Matters

\section{Statistical analysis}

The cumulative values of the four seasons were used as the proportional abundance of each FFG. Analysis of variance (ANOVA) was used to determine differences between the sites and seasons. Where there was a significant variation, the Turkey's Post-Hoc test was performed to determine where the difference occurred. The statistical analyses were conducted using the software package, Statistica v10.0. Canonical Correspondence analysis (CCA), a multivariate method to calculate the relationships between biological assemblages of taxa and the environment was also used (Ter Braak and Verdonschot, 1995).

\section{Results}

\section{Physicochemical variables}

The mean values of the physicochemical parameters are summarized in Table 3. The water depth and width increased from upstream to downstream site. The mean depth varied from $0.25 \mathrm{~m}(\mathrm{~S} 1)$ to $0.68 \mathrm{~m}(\mathrm{~S} 3)$ and the mean width varied from 4.97 (S1) to $7.07 \mathrm{~m}$ (S7). The highest mean velocity was $0.37 \mathrm{~m} / \mathrm{s}$ at $\mathrm{S} 3$ and the lowest was $0.21 \mathrm{~m} / \mathrm{s}$ at $\mathrm{S} 1$. The $\mathrm{pH}$ ranged from 8.1 at $\mathrm{S} 5$ to 9.0 at $\mathrm{S} 1$. The mean temperature varied from 22.28 (S2) to $24.90{ }^{\circ} \mathrm{C}$ (S7). The lowest mean dissolved oxygen value of $8.70 \mathrm{mg} / 1$ and the highest mean value of $11.85 \mathrm{mg} / \mathrm{l}$ were recorded at S5 and S2 respectively. The highest mean conductivity of $442 \mathrm{mS} / \mathrm{m}$ was observed at S5 and the lowest mean conductivity of $270.85 \mathrm{mS} / \mathrm{m}$ at S1. The mean TDS ranged from 132.9 at S1 to $252 \mathrm{mg} / 1$ at $\mathrm{S} 7$. There were no significant differences in the physicochemical variables among the seven sites $(p>0.05)$. However, there were seasonal significant differences in temperature (ANOVA, $\mathrm{F}=12.03$; $\mathrm{p}<0.001$ ), DO (ANOVA, $\mathrm{F}=8.16 ; \mathrm{p}=0.001$ ), EC (ANOVA, $\mathrm{F}=3.45 ; \mathrm{p}=0.032$ ), TDS (ANOVA, $\mathrm{F}=18.6 ; \mathrm{p}<0.001$ ). The nutrient levels were generally higher at the upstream sites than the downstream sites. 
Table 3. The mean physicochemical variables measured at different sites along the Blyde River

\begin{tabular}{|c|c|c|c|c|c|c|c|c|c|c|c|c|c|c|c|}
\hline \multirow{2}{*}{$\begin{array}{c}\text { Water quality } \\
\text { parameters }\end{array}$} & \multicolumn{2}{|c|}{ S1 } & \multicolumn{2}{|c|}{ S2 } & \multicolumn{2}{|c|}{ S3 } & \multicolumn{2}{|c|}{ S4 } & \multicolumn{2}{|c|}{ S5 } & \multicolumn{2}{|c|}{ S6 } & \multicolumn{2}{|l|}{ S7 } & \multirow[t]{2}{*}{ WQG } \\
\hline & AVE & SD & AVE & $\pm \mathbf{S D}$ & AVE & SD & AVE & $\pm \mathbf{S D}$ & AVE & SD & AVE & $\pm \mathbf{S D}$ & VE & NO & \\
\hline veloc & 0.21 & 0.11 & 0.26 & \begin{tabular}{|l|}
0.12 \\
\end{tabular} & 37 & 0.04 & .32 & 0.14 & .35 & 0.12 & 32 & 0.15 & .35 & 0.06 & \\
\hline & 2.33 & 01 & 28 & 2.30 & 3.53 & 1.71 & \begin{tabular}{|l|}
22.88 \\
\end{tabular} & 2.54 & 23.65 & 2.58 & 23.95 & 3.49 & 4.90 & 3.49 & \\
\hline $\mathrm{pH}$ & -9.0 & - & 8.4-8.9 & - & $8.3-8.7$ & - & $8.2-8.8$ & - & $8.1-8.5$ & - & $8.2-8.8$ & - & $8.2-8.8$ & - & \\
\hline $\mathrm{EC}(\mathrm{mS} / \mathrm{s}$ & 270.85 & 346.6 & 274.9 & 361.8 & 341.4 & 260.6 & 338.9 & 449.8 & 442.2 & 547.0 & 366.7 & 357.8 & 33.7 & 357.8 & 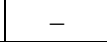 \\
\hline TDS (mg/l) & 132.9 & 32.2 & 138.5 & 35.4 & 147.2 & 43.7 & 250.9 & 158.0 & 241.2 & 79.4 & 158.6 & 76.64 & 252.8 & 76.64 & \\
\hline $\mathrm{DO}(\mathrm{n}$ & \begin{tabular}{|l|}
11.01 \\
\end{tabular} & 1.345 & 11.85 & 2.45 & 9.93 & 2.45 & 10.7 & 1.33 & 8.70 & 1.85 & 9.38 & 1.31 & 10.63 & 0.15 & - \\
\hline Salini & & & & & 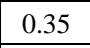 & | & 38 & 0.51 & 0.46 & 0.59 & .38 & 0.51 & 9.49 & 0.63 & $<0.5 \%{ }^{1}$ \\
\hline $\mathrm{NO}_{2} \mathrm{C}$ & 0.02 & 0.01 & 0.01 & 0.00 & 0.01 & \begin{tabular}{|l|}
0.00 \\
\end{tabular} & 0.00 & \begin{tabular}{|l|}
0.00 \\
\end{tabular} & 0.01 & 0.01 & 0.00 & \begin{tabular}{|l|}
0.00 \\
\end{tabular} & 0.005 & \begin{tabular}{|l|}
0.00 \\
\end{tabular} & $0.06^{3}$ \\
\hline $\mathrm{NO}_{3}(\mathrm{mg} / \mathrm{l})$ & 65 & 050 & 55 & 0.10 & 02 & 0.00 & 15 & 0.00 & .25 & 0.00 & .33 & 0.05 & 375 & 0.05 & $13.0^{3}$ \\
\hline & 0 & 0 & 0.05 & 0 & 004 & 0.00 & 05 & 0.00 & 03 & 0.00 & 0.03 & 0.03 & 0.065 & 0.03 & \\
\hline $4\left(\operatorname{lig}^{\prime \prime \prime}\right.$ & & 0.00 & 0.10 & 0.32 & 0.70 & 0.00 & $0.2 \mathrm{~J}$ & 0.00 & 0.03 & 0.00 & 0.18 & 0.20 & 0.13 & 0.20 & - \\
\hline Turbidity NTU & 10.70 & 8.69 & 11.20 & 12.88 & 6.75 & 2.05 & 7.50 & 2.69 & 13.25 & 10.99 & 7.75 & 5.24 & 10.25 & 3.34 & $8-<50^{2}$ \\
\hline
\end{tabular}

${ }^{1}$ DWAF (1996) - South African Water Quality Guidelines: Volume 7: Aquatic Ecosystems

${ }^{2}$ BC-EPD (2006) -British Columbia Environmental Protection Division: Water Quality Guidelines

${ }^{3}$ CCME (2012) - Canadian Council of Ministers of the Environment: Water Quality Guidelines-Aquatic Life

${ }^{4}$ US-EPA (2012) - United States Environmental Protection Agency: Water Quality Guidelines-Aquatic Life

\section{Abundance and diversity of macroinvertebrates}

A total of 19797 specimens belonging to 11 orders and 33 families were collected at the various sampling sites and seasons. The greatest abundance (7426) and least abundance (1023) were observed at S5 and S3 respectively. The highest taxa richness (31) and the lowest taxa richness (22) were at S6 and S7 respectively. The family Hydropsychidae (Trichoptera) was the dominant taxa, followed by Caenidae, Baetidae (Ephemeroptera) and Simuliidae (Diptera) (Table 4). The abundance of the macroinvertebrates was significantly different among sampling sites (ANOVA, $\mathrm{F}=8.35 ; \mathrm{p}<0.001)$. In terms of seasons, the most abundance occurred during winter and least abundance during summer. The highest taxa richness (32) occurred in spring, followed by winter (27), autumn (24) and then summer (23). There was no seasonal significant difference in taxa richness but there was a significant seasonal variation in abundance (ANOVA, $\mathrm{F}=6.03 ; \mathrm{p}<0.001$ ).

\section{Functional feeding group composition}

In terms of the functional feeding groups, 14 predators, 8 collector-gatherers, 6 scrapers, 4 collector-filterers, 3 shredders were collected (Table 4). The collectorgatherers and collector-filterers accounted for about $80 \%$ of the total abundance (Fig. 2). The highest abundance of collector filterers, collector-gatherers and shredders were at S5, the highest abundance of predators and scrapers were at S2 and S7 respectively (Table 5). There were significant variations in the FFGs among the sites ((ANOVA: $\mathrm{F}=4.35, \mathrm{p}<0.05)$. There was a significant difference in the abundance of collector-filterers among sampling sites (ANOVA, $\mathrm{F}=3.88 ; \mathrm{p}=0.009$ ) and the postdoc showed the significant difference between S1 and S5 (Tukey's test $=0.025$ ), S3 and S5 (Tukey's test $=0.026$ ), S4 and S5 (Tukey's test $=0.017$ ) and S5 and S7 (Tukey's test $=0.015)$ (Table A2 in the Appendix). The collector-gatherers showed a significant 
seasonal variation (ANOVA, $\mathrm{F}=3.06 ; \mathrm{p}=0.04$ ) and the postdoc showed the significant difference between winter and summer (Tukey's test =0.048) (Table A9).

Table 4. Order, families and the functional feeding groups of macroinvertebrates from the Blyde River

\begin{tabular}{|c|c|c|c|c|c|c|c|c|c|c|}
\hline Order & Family & S1 & S2 & S3 & S4 & S5 & S6 & S7 & Total & FFG \\
\hline \multirow{6}{*}{ Ephemeroptera } & Baetidae & 227 & 594 & 138 & 417 & 501 & 330 & 276 & 2483 & $\mathrm{CG}$ \\
\hline & Caenidae & 490 & 722 & 91 & 85 & 612 & 396 & 123 & 2519 & $\mathrm{CG}$ \\
\hline & Heptageniidae & 7 & 123 & 95 & 270 & 103 & 267 & 40 & 905 & $\mathrm{Sc}$ \\
\hline & Teloganodidae & 39 & 68 & 13 & 20 & 139 & 101 & 295 & 675 & $\mathrm{CG}$ \\
\hline & Leptophlebiidae & 1 & 3 & 20 & 3 & & 53 & 76 & 156 & $\mathrm{CG}$ \\
\hline & Tricorythidae & 4 & 3 & 15 & 37 & 532 & 24 & 128 & 743 & CG \\
\hline \multirow{3}{*}{ Trichoptera } & Hydropsychidae & 207 & 754 & 390 & 131 & 1308 & 631 & 260 & 3681 & $\mathrm{CF}$ \\
\hline & Philopotamidae & & 11 & 17 & 15 & 226 & 2 & 2 & 273 & $\mathrm{CF}$ \\
\hline & Leptoceridae & 1 & 2 & 3 & & & & & 5 & $\mathrm{Sh} / \mathrm{CG}$ \\
\hline \multirow{4}{*}{ Coleoptera } & Gyrinidae & 1 & 8 & 1 & 3 & 1 & 8 & 1 & 23 & $\mathrm{P}$ \\
\hline & Elmidae & 23 & 72 & 31 & 52 & 917 & 52 & 13 & 1160 & $\mathrm{CG} / \mathrm{Sc} / \mathrm{Sh}$ \\
\hline & Helodidae & 3 & & 2 & & 9 & 1 & & 15 & Sh \\
\hline & Psephenidae & 24 & 12 & 38 & 21 & 1 & 17 & & 113 & $\mathrm{Sc}$ \\
\hline \multirow{6}{*}{ Odonata } & Libellulidae & 10 & 12 & 6 & 5 & 50 & 4 & 10 & 97 & $\mathrm{P}$ \\
\hline & Chlorocyphidae & 50 & 192 & 53 & 89 & 1 & 75 & 3 & 463 & $\mathrm{P}$ \\
\hline & Platycnemididae & & 3 & 2 & & & 1 & & 6 & $\mathrm{P}$ \\
\hline & Coenagrionidae & 1 & & 1 & 4 & 5 & 3 & 3 & 17 & $\mathrm{P}$ \\
\hline & Aeshnidae & 8 & 8 & & 2 & 1 & 1 & & 20 & $\mathrm{P}$ \\
\hline & Gomphidae & 68 & 21 & 3 & 2 & 2 & 1 & 14 & 111 & $\mathrm{P}$ \\
\hline \multirow{7}{*}{ Diptera } & Athericidae & 4 & 79 & 7 & 25 & 13 & 40 & 1 & 169 & $P$ \\
\hline & Blephariceridae & & & & & 2 & 8 & & 10 & $\mathrm{Sc}$ \\
\hline & Tabanidae & 11 & 8 & 5 & 7 & 79 & 19 & 11 & 140 & $\mathrm{P}$ \\
\hline & Dixidae & & & 1 & 2 & 5 & 3 & & 11 & $\mathrm{CG}$ \\
\hline & Chironomidae & 59 & 66 & 37 & 58 & 975 & 246 & 62 & 1503 & $\mathrm{CG}$ \\
\hline & Muscidae & & 1 & & & 3 & 2 & & 6 & $\mathrm{P}$ \\
\hline & Simuliidae & 11 & 26 & 11 & 80 & 1223 & 854 & 12 & 2217 & $\mathrm{CF}$ \\
\hline Plecoptera & Perlidae & 1 & 5 & 2 & 3 & 9 & 6 & & 26 & $\mathrm{P}$ \\
\hline \multirow{2}{*}{ Annelida } & Hirudinea & & & & & 36 & 57 & & 93 & $P$ \\
\hline & Oligochaeta & 18 & 7 & 3 & 2 & 4 & 32 & 42 & 108 & $\mathrm{CG}$ \\
\hline \multirow{4}{*}{ Mollusca } & Physidae & & & & & 1 & & 2 & 3 & $\mathrm{Sc}$ \\
\hline & Planorbidae & 1 & 3 & & 2 & & 17 & & 23 & $\mathrm{Sc}$ \\
\hline & Thiaridae & 38 & 45 & 41 & 3 & 23 & 152 & 642 & 944 & $\mathrm{Sc}$ \\
\hline & Corbiculidae & 3 & 14 & 5 & 43 & 635 & 239 & 140 & 1079 & $\mathrm{CF}$ \\
\hline \multicolumn{2}{|c|}{ Total of individuals } & 1309 & 2862 & 1031 & 1381 & 7416 & 3642 & 2156 & 19797 & \\
\hline Taxa richness & & 24 & 24 & 27 & 26 & 29 & 31 & 22 & & \\
\hline
\end{tabular}

FFGs: collector-filterers (CF), collector-gatherers (CG), predators (P), scrapers (Sc) and shredders (Sh)

\section{Relationships between macroinvertebrates (FFG) and physicochemical variables}

The CCA ordination of macroinvertebrate FFGs with water quality variables and nutrient concentrations showed distinct patterns, where the variables correlated with specific macroinvertebrate FFG under different levels of disturbance (Fig. 3). Sites 6 and 7 were less affected by temperature, EC, TDS, turbidity and nitrate. There was an association of shredders with the upstream sites, S1 and S2, while scrapers were associated with S3 and S4. The predators and the collectors (filterers and gatherers) 
were well distributed at all the sites. The eigenvalues were $0.090,0.058,0.046$ and 0.032 for the axis 1 , axis 2 . axis 3 and 4 , and explained $34.7 \%, 58.4 \%, 74.0 \%$ and $86.8 \%$ of variance respectively (Table 6).

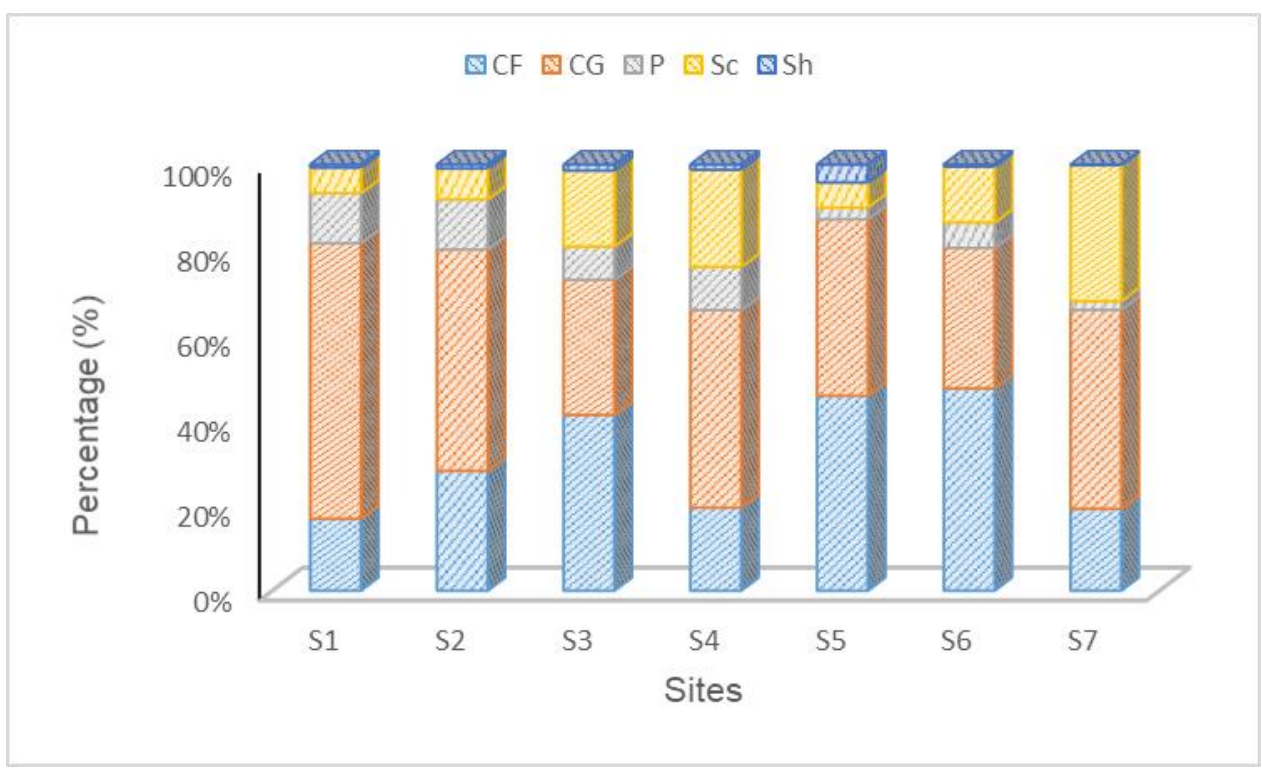

Figure 2. Composition of the FFGs of aquatic insects at the different sites in the Blyde River (CF-collector filterer, $C G$ - collector gatherer, $P$ - predator, $S c$ - scrapers, Sh-shredders)

Table 5. Abundance of the functional feeding groups (FFGs) of macroinvertebrates in the seven study sites of the Blyde River

\begin{tabular}{c|c|c|c|c|c|c|c}
\hline & CF & CG & P & Sc & Sh & $\begin{array}{c}\text { Relative } \\
\text { abundance (\%) }\end{array}$ & Total \\
\hline S1 & 221 & 846 & 154 & 78 & 10 & 6.6 & 1309 \\
S2 & 805 & 1486 & 337 & 207 & 27 & 14.5 & 2862 \\
S3 & 425 & 327 & 80 & 184 & 15 & 5.2 & 1031 \\
S4 & 269 & 640 & 140 & 315 & 17 & 7.0 & 1381 \\
S5 & 3392 & 3073 & 200 & 436 & 315 & 37.4 & 7416 \\
S6 & 1727 & 1202 & 217 & 478 & 18 & 18.4 & 3642 \\
S7 & 414 & 1006 & 44 & 688 & 4 & 10.9 & 2156 \\
Relative abundance (\%) & 36.6 & 43.3 & 5.9 & 12.1 & 2.1 & 100 & 19797 \\
\hline
\end{tabular}

FFGs: collector-filterers $(\mathrm{CF})$, collector-gatherers $(\mathrm{CG})$, predators $(\mathrm{P})$, scrapers $(\mathrm{Sc})$ and shredders $(\mathrm{Sh})$

Table 6. The canonical correspondence analysis (CCA) between functional feeding groups and environmental variables for the Blyde River

\begin{tabular}{c|c|c|c|c|c}
\hline Axes & $\mathbf{1}$ & $\mathbf{2}$ & $\mathbf{3}$ & $\mathbf{4}$ & Total \\
\hline Eigenvalues & 0.090 & 0.058 & 0.046 & 0.032 & 0.247 \\
Taxa-environment correlations & 0.99 & 0.99 & 0.99 & 0.99 & \\
\% variance explained & & & & & \\
$\quad$ - of taxa data & 34.7 & 58.4 & 74.0 & 86.8 & \\
- of taxa-environment relation & 34.7 & 58.4 & 74.0 & 86.8 & \\
\hline
\end{tabular}




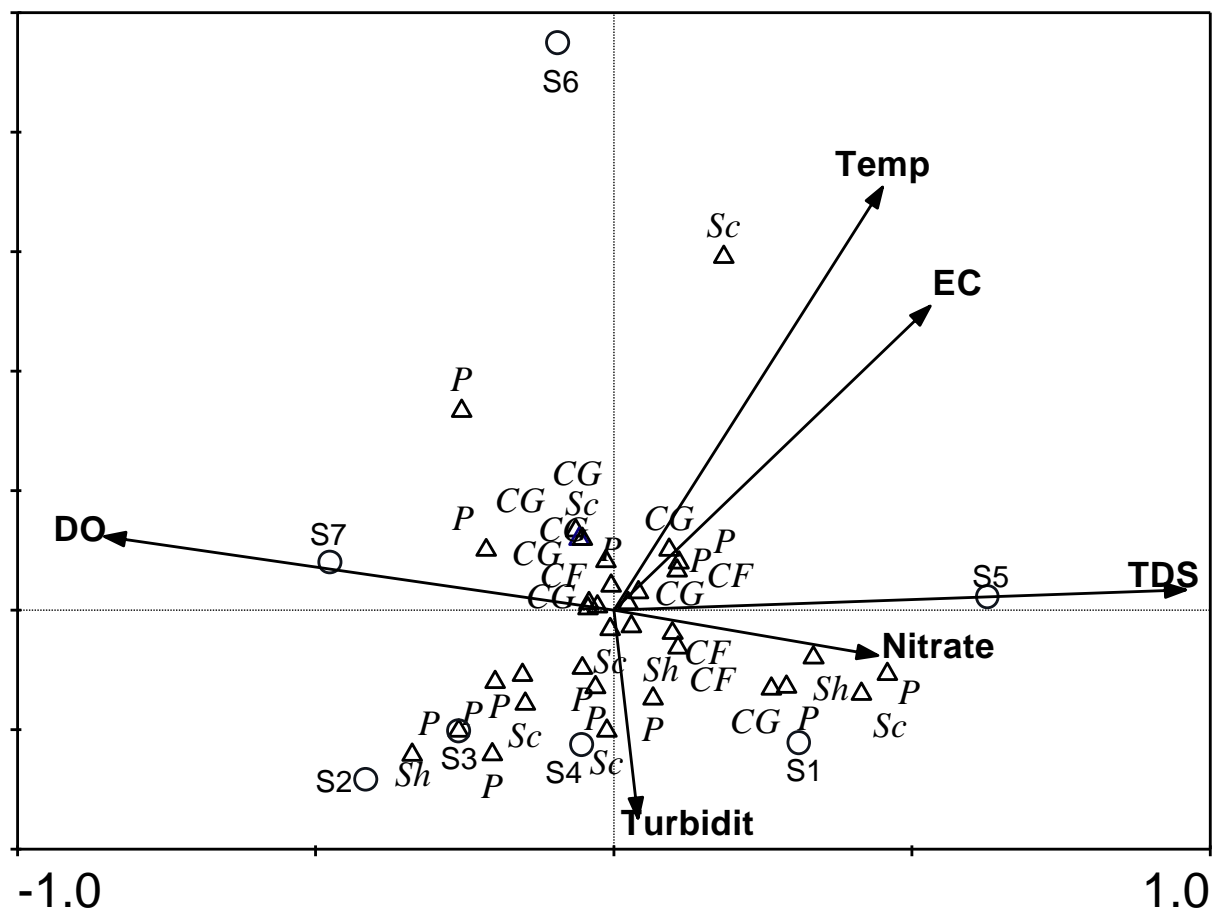

Figure 3. CCA tri-plot of the relationship between physicochemical variables and functional feeding groups of macroinvertebrates (CF-collector filterer, $C G$ - collector gatherer, $P$ predator, Sc-scrapers, Sh-shredders)

\section{Discussion}

\section{Physicochemical variables}

Generally, the high levels of dissolved oxygen and low nutrient levels indicate that the water in the Blyde River was of good quality and that the river was only slightly disturbed by human activities. Higher EC and TDS were recorded in the midstream and downstream (from S4 to S7) than upstream (S1 and S2) of the river. The dissolved oxygen was high throughout the river, an indication that the river is in good condition. The nutrient levels were generally low at all sites. Thus, the physicochemical variables and nutrients recorded at all the sites were within the guideline limits (DWAF, 1996; CCME, 2012; USEPA, 2012).

\section{Abundance and diversity of macroinvertebrates}

The highest richness and abundance of macroinvertebrates were at S6 and S5 respectively. The high abundance of macroinvertebrates at site S5 could be attributed to increased input of organic nutrients from agriculture and high habitat heterogeneity of the site. High abundance of macroinvertebrates is known to increase with higher habitat heterogeneity due to the available stable and diverse microhabitats (Braccia and Voshell, 2006). The highest macroinvertebrate taxon richness at S6 could be due good habitat condition and the canopy cover. Many studies have found higher macroinvertebrate taxon richness at shaded sites than sites with low canopy cover (Dalu et al., 2017). The improved habitat condition at S5, though at the downstream of the river further supports the importance of conservation of water resources. The observed 
differences in taxa compositions across the sites were most likely due to different land use characteristics (Cortes et al., 2011, 2013).

\section{Functional feeding group composition of macroinvertebrates}

The collectors (filterers and gatherers) were dominant at all the sites. The high abundance across the sites could be due to the wide range of food resources consumed by this group. The predominance of collectors throughout the river has been reported in other studies of tropical streams (Tomanova et al., 2006; Jiang et al., 2011). Collectors are commonly abundant in streams and typically increase in abundance with stream size (Vannote et al., 1980). Generally, the high abundance of collector-gatherers in the river could be attributed to enrichment of organic matter in the water (Rosenberg and Resh, 1993). The highest abundance of collector-filterers was at S5, followed by S6. This may be attributed to the relative abundance of fine particulate organic matter transported in the water column (Strand and Merritt, 1999).

The high taxa richness of predators along the whole longitudinal gradients of the river may be due to availability of food and less competition. Predators are more abundant in small intermittent streams where fishes are scarce (Rieradevall et al., 1999). The river continuum concept (RCC) proposed that the abundance of predators depend on prey availability and abundance (Vannote et al., 1980). Predators normally have a similar proportion along the entire river, according to the river continuum concept or, alternatively, their abundance may depend on prey availability (Vannote et al., 1980). In this study, the relative abundance of predators was not significantly different at all sites except at S3 and S7. The highest abundance of scrapers at S7 could be due to sufficient algal production (periphyton), which serves as their food (Grubaugh et al., 1996). The shredders abundance was generally low especially at S7. Generally, the low abundance of shredders could be attributed to the enhanced microbial activity replacing shredder activity at high temperatures. The highest abundance at S5 could be due to the presence of riparian canopy which created conditions with plenty of feeding material that supported the shredders. The shredders utilize leaf litter from the riparian zones as an energy source. On the contrary, the lowest abundance of shredders at S7 could be due to low availability of leaf litter. Similar results have been reported that shredders are intimately related to the riparian vegetation, because of their reliance on allochthonous feeding resources and as well contribute much in the degradation of leaf materials dropping into aquatic systems from overhanging vegetation (Brasil et al., 2014; Masese et al., 2014).

The variation of the different FFG at the sampling sites can be explained by the availability of the food resources and changes in the environmental variables. Studies have shown that macroinvertebrate fauna can be altered by land use practices (Miserendino and Masi, 2010; Egler et al., 2012; Fierro et al., 2015). The shredders and scrapers were very low in the river and this could also be due to the fact that these two groups are more sensitive to disturbances, while collector-gatherers and collectorfilterers are more tolerant to pollution that might alter the availability of certain food (Barbour et al., 1996). Thus, the functional groups can potentially be used to assess aquatic ecosystem health (Bhawsar et al., 2015). Studies on the distribution of FFGs and benthic macroinvertebrate assemblages according to environmental variables are increasingly being conducted (Fierro et al., 2015; Fu et al., 2016).

Seasonally, the taxon richness and abundance were highest in spring and winter respectively than in other seasons. These are the drier seasons of the year and therefore 
the river receives less runoff draining from the catchment. In general, factors driving macroinvertebrate seasonal variation include precipitation/discharge, temperature, and photoperiod, and each of these factors can influence disturbance regimes in streams (Bêche et al., 2006). Seasonal variation of macroinvertebrate distribution can also be caused by changes in current velocity, substrate type and organic matter. The collectorgatherers were the most dominant functional group in autumn, winter and spring, while the collector-filterers were the most dominant group in summer. According to the continuum river concept, low order rivers such as Blyde River should contain mainly collector-gatherers and shredder organisms (Vannote et al., 1980). However, in this study the predominant group was the collector-gatherer. This study supports other studies which found high abundance of only collectors' group in some rivers (Miserendino and Pizzolon, 2003).

\section{Relationships between macroinvertebrate assemblages and water quality variables}

The distribution of macroinvertebrate structural and functional assemblages was influenced by physicochemical variables and nutrients across the sites. Canonical correspondence analysis (CCA) indicated that specific site categories correlated with specific water quality variables which in turn affected the distribution of the macroinvertebrates. Shredders were mainly found in the sites with riparian influence. Increase in nutrient levels and reduction in water quality negatively impacted the distribution of the sensitive macroinvertebrate taxa. The deteriorating physicochemical variables (EC and TDS) at S4 and S7 contributed to the low richness and diversity of macroinvertebrate taxa in these sites. Macroinvertebrate distribution closely followed the observed land-use changes in the various sites which induced changes in water quality with the least disturbed sites being associated with macroinvertebrate communities that were different from sites with poor water quality. These results are consistent with many other studies that have also found abiotic factors to be significantly affecting variation in macroinvertebrate communities (Kasangaki et al., 2008; Masese et al., 2014).

\section{Conclusion}

The study determined the influence of physicochemical variables on the distribution of benthic macroinvertebrate FFG. The collector-gatherers and collector filterers dominated across all the sites. The shredder and collector co-dominance in the headwaters was not observed as predicted by RCC. The RCC predicts that shredders will decrease in abundance from headwaters to the mouth and that collector-gatherers, collector-filterers and scrapers will increase downstream (Vannotte et al., 1980). Generally, low abundance of shredders and scrapers were recorded in this study. Thus, the distribution of the functional groups did not conform fully to RCC pattern and it could be due to land use changes (degradation) occurring in sections of the river. The high richness of macroinvertebrates at S6 further supports the importance of conservation. The FFG pattern shows the influence of changing environmental conditions on macroinvertebrates along the river and therefore confirm that FFG is an effective tool to assess ecological integrity of rivers. The findings suggest that conservation and protection of the river catchment including the riparian zone are important for preservation of ecological integrity and biodiversity of rivers. Future 
studies should consider how the increasing land use changes and climate change will affect the structure of macroinvertebrates in the river.

Acknowledgments. Financial support for this study was granted by the Flemish Interuniversity Council (VLIR-UOS), Belgium for providing financial support for the study. I thank the postgraduate students in the Water Laboratory, University of Limpopo for their valuable contributions with the field work.

Conflict of interests. The author declares no conflict of interests.

\section{REFERENCES}

[1] Addo-Bediako, A., Matlou, K., Makushu, E. (2018): Heavy metal concentrations in water and sediment of the Steelpoort River, Olifants River System, South Africa. - African Journal of Aquatic Sciences 43: 413-416.

[2] Allan, J. D., Castillo, M. M. (2007): Stream Ecology: Structure and Function of Running Waters. $2^{\text {nd }}$ Ed. - Springer, Dordrecht.

[3] Ashton, P. J., Dabrowski, J. M. (2011): An Overview of Water Quality and the Causes of Poor Water Quality in the Olifants River Catchment. - WRC Report No. K8/887. Water Research Commission of South Africa, Pretoria.

[4] Barbour, M., Gerritsen, J., Griffith, G., Frydenborg, R., Mccarron, E., White, J., Bastian, M. A. (1996): A framework for biological criteria for Florida streams using benthic macroinvertebrates. - Journal of the North American Benthological Society 15(2): 185211.

[5] Bêche, L. A., Mcelravy, E. P., Resh, V. H. (2006): Longterm seasonal variation in the biological traits of benthic-macroinvertebrates in two Mediterranean-climate streams in California, USA. - Freshwater Biology 51: 56-75.

[6] Bhawsar, A., Bhat, M. A., Vyas, V. (2015): Distribution and composition of macroinvertebrates functional feeding groups with reference to catchment area in Barna Sub-Basin of Narmada River Basin. - International Journal of Scientific Research and Engineering 3(11): 385-393.

[7] Braccia, A., Voshell, J. R. (2006): Benthic macroinvertebrate responses to increasing levels of cattle grazing in Blue Ridge Mountain Streams, Virginia, USA. - Environmental Monitoring and Assessment 131: 185-200.

[8] Brasil, L. S., Shimano, Y., Batista, J. D., Cabette, H. S. R. (2013): Effects of environmental factors on community structure of Leptophlebiidae (Insecta: Ephemeroptera) in Cerrado streams, Brazil. - Iheringia Série Zoologia 103: 260-265.

[9] CCME (Canadian Council of Ministers of the Environment) (2012): Environmental Quality Guidelines: Water Quality Guidelines for the Protection of Aquatic Life and Sediment Quality Guidelines for the Protection of Aquatic Life. - Canadian Council of Ministers of the Environment, Winnipeg. http://ceqg rcqe.ccme.ca/ (accessed 11 March, 2020).

[10] Chen, N., Chen, L., Ma, Y., Chen, A. (2019): Regional disaster risk assessment of China based on self-organizing map: clustering, visualization and ranking. - International Journal of Disaster Risk Reduction 33: 196-206.

[11] Cortes, R. M. V., Hughes, S. J., Pereira, V. R., Varandas, S. D. G. P. (2013): Tools for bioindicator assessment in rivers: the importance of spatial scale, land use patterns and biotic integration. - Ecological Indicators 34: 460-477.

[12] Cortes, R., Varandas, S., Teixeira, A., Hughes, S., Magalhaes, M., Barquín, J., ÁlvarezCabria, M., Fernández, D. (2011): Effects of landscape metrics and land use variables on macroinvertebrate communities and habitat characteristics. - Limnetica 30: 347-362.

[13] Cummins, K. W. (2016): Combining taxonomy and function in the study of stream macroinvertebrates. - Journal of Limnology 75(s1): 235-241. 
[14] Cummins, K. W., Merritt, R. W., Andrade, P. C. N. (2005): The use of macroinvertebrate functional groups to characterize ecosystem attributes in selected streams and rivers in south Brazil. - Studies on Neotropical Fauna and Environment 40(1): 69-89.

[15] Dalu, T., Wasserman, R. J., Tonkin, J. D., Mwedzi, T., Magoro, M. L., Weyl, O. L. F. (2017): Water or sediment? Partitioning the role of water column and sediment chemistry as drivers of macroinvertebrate communities in an austral South African stream. - Science of the Total Environment 607-608: 317-325. DOI: 10.1016/j.scitotenv.2017.06.267.

[16] De Castro, D. M. P., de Carvalho, D. R., Pompeu, P. D. S., Moreira, M. Z., Nardoto, G. B., Callisto, M. (2016): Land use influences niche size and the assimilation of resources by benthic macroinvertebrates in tropical headwater streams. - PLoS One 11(3): e0150527. DOI: 10.1371/journal.pone.0150527.

[17] Dickens, C. W., Graham, P. (2002): The South African Scoring System (SASS) version 5 rapid bio-assessment method for rivers. - African Journal of Aquatic Sciences 27: 1-10.

[18] DWAF (Department of Water Affairs and Forestry) (1996): South African Water Quality Guidelines Volume 7: Aquatic Ecosystems. - Department of Water Affairs and Forestry, Pretoria, South Africa.

[19] DWAF (Department of Water Affairs and Forestry) (2004): Olifants Water Management Area: Internal Strategic Perspective. - DWAF, Cape Town, South Africa.

[20] Egler, M. A., Buss, D. F., Moreira, J. C. B., Baptista, D. F. (2012): Influence of agricultural land-use and pesticides on benthic macro invertebrate assemblages in an agricultural river basis in southeast Brazil. - Brazilian Journal of Biology 3: 437-443.

[21] Ferreira, V., Encalada, A. C., Graça, M. (2012): Effects of litter diversity on decomposition and biological colonization of submerged litter in temperate and tropical streams. Freshwater Science 31: 945-962.

[22] Fierro, P., Bertran, C., Mercado, M., Pena-Cortes, F., Tapia, J., Hauenstein, E., Caputo, L., Vargas-Chacoff, L. (2015): Landscape composition as a determinant of diversity and functional feeding groups of aquatic macroinvertebrates in southern rivers of the Araucania, Chile. - Latin American Journal of Aquatic Research 43(1): 186-200.

[23] Fu, L., Jiang, Y., Ding, J., Liu, Q., Peng, Q. Z., Kang, M. Y. (2016): Impacts of land use and environmental factors on macroinvertebrate functional feeding groups in the Dongjiang River basin, southeast China. - Journal of Freshwater Ecology 31(1): 21-35.

[24] Gerber, A., Gabriel, M. J. M. (2002): Aquatic Invertebrates of South African Rivers: Field Guide. - Department of Water Affairs and Forestry, Pretoria, South Africa.

[25] Ghasemi, A. F., Kamali, M. (2014): Benthic macroinvertebrates along the Haraz downstream in Southern Caspian Sea Basin: in gradient of the physicochemical parameters. - International Journal of Zoology 2014: 7. DOI: 10.1155/2014/145430.

[26] Grubaugh, J. W., Wallace, J. B., Houston, E. S. (1996): Longitudinal changes of macroinvertebrate communities along an Appalachian stream continuum. - Canadian Journal of Fisheries and Aquatic Sciences 53: 896-909.

[27] Jiang, X., Xiong, J., Xie, Z., Chen, Y. (2011): Longitudinal patterns of macroinvertebrate functional feeding groups in a Chinese river system: a test for river continuum concept (RCC). $\quad-\quad$ Quaternary International 244(2): $289-295$. https://doi.org/10.1016/j.quaint.2010.08.015.

[28] Jooste, A., Marr, S. M., Addo-Bediako, A., Luus-Powell, W. J. (2015): Sharptooth catfish shows its metal: a case study of metal contamination at two impoundments in the Olifants River System, South Africa. - Ecotoxicology and Environmental Safety 112: 96-104.

[29] Jun, Y-C., Kim, N-Y., Kim, S-H., Park, Y-S., Kong, D-S., Hwang, S-J. (2016): Spatial distribution of benthic macroinvertebrate assemblages in relation to environmental variables in Korean nationwide streams. - Water 8(1): 27.

[30] Kasangaki, A., Chapman, L. J., Balirwa, J. (2008): Land use and the ecology of benthic macroinvertebrate assemblages of high-altitude rainforest streams in Uganda. - Freshwater Biology 53: 681-697. 
[31] Kim, D-H., Chon, T-S., Kwak, G-S., Lee, S-B., Park, Y-S. (2016): Effects of land use types on community structure patterns of benthic macroinvertebrates in streams of urban areas in the South of the Korea Peninsula. - Water 8(5): 187.

[32] Li, L., Zheng, B., Liu, L. (2010): Biomonitoring and bioindicators used for river ecosystems: definitions, approaches and trends. - Procedia Environmental Sciences 2: 1510-1524.

[33] Masese, F. O., Kitaka, N., Kipkemboi, J., Gettel, G. M., Irvine, K., McClain, M. E. (2014): Macroinvertebrate functional feeding groups in Kenyan highland streams: evidence for a diverse shredder guild. - Freshwater Science 33: 435-450. DOI: $10.1086 / 675681$.

[34] Merritt, R. W., Cummins, K. W. (1996): An Introduction to the Aquatic Insects of North America. $3^{\text {rd }}$ Ed. - Kendall/Hunt Publishing Co., Dubuque, Iowa.

[35] Merritt, D. M., Manning, M. E., Hough-Snee, N. (2017): The National Riparian Core Protocol: A Riparian Vegetation Monitoring Protocol for Wadeable Streams of the Conterminous United States. - Gen. Tech. Rep. RMRS-GTR-367. Department of Agriculture, Forest Service, Rocky Mountain Research Station, Fort Collins, CO.

[36] Mimba, M. E., Ohba, T., Fils, S. C. N., Nforba, M. T., Numanami, N., Bafon, T. G., Festus, T. A., Suh, C. E. (2018): Regional geochemical baseline concentration of potentially toxic trace metals in the mineralized Lom Basin, East Cameroon: a tool for contamination assessment. - Geochemical Transactions 19(1): 11.

[37] Miserendino, M. L., Masi, C. I. (2010): The effects of land use on environmental features and functional organization of macroinvertebrate communities in Patagonian low order streams. - Ecological Indicators 10: 311-319.

[38] Miserendino, M. L., Pizzolon, L. A. (2003): Distribution of macroinvertebrate assemblages in the Azul-Quemquemtreu river basin, Patagonia, Argentina. - New Zealand Journal of Marine and Freshwater Research 37: 525-539. DOI: $10.1080 / 00288330.2003 .9517187$.

[39] Mishra, A. S., Nautiyal, P. (2013): Functional composition of benthic macroinvertebrate fauna in the plateau rivers, Bundelkhand, central India. - Journal of Threatened Taxa 5(13): 4752-4758.

[40] Príncipe, R. E., Gualdoni, C. M., Oberto, A. M., Raffaini, G. B., Corigliano, M. C. (2010): Spatial-temporal patterns of functional feeding groups in mountain streams of Córdoba, Argentina. - Ecología Austral 20: 257-268.

[41] Qu, X., Cho, W-S., Hwang, H-J., Tang, H., Liu, Y., Choi, J-H., Jung, M., Chung, B. S., Lee, H. Y., Chung, Y. R., Koh, S-C. (2013): Evaluation of stream ecosystem health and species association based on multi-taxa (benthic macroinvertebrates, algae, and microorganisms) patterning with different levels of pollution. - Ecological Informatics 17: 58-72.

[42] Rieradevall, M., Bonada, N., Prat, N. (1999): Community structure and water quality in the Mediterranean streams of a natural park (St. Llorenc, del Munt, NE Spain). - Limnetica 17: 45-56.

[43] Rosenberg, D. M., Resh, V. H. (1993): Freshwater Biomonitoring and Benthic Macroinvertebrates. - Chapman and Hall, London.

[44] Strand, M., Merritt, R. W. (1999): Impacts of livestock grazing activities on stream insect communities and the riverine environment. - American Entomologist 45: 13-29.

[45] Ter Braak, C. J. F., Verdonschot, P. F. M. (1995): Canonical Correspondence Analysis and related multivariate methods in aquatic ecology. - Aquatic Science 57: 255-289.

[46] Tomanova, S., Goitia, E., Helešic, J. (2006): Trophic levels and functional feeding groups of macroinvertebrates in Neotropical streams. - Hydrobiologia 556(1): 251-264. https://doi.org/10.1007/s10750-005-1255-5.

[47] Townsend, C. R., Arbuckle, C. J., Crowl, T. A., Scarsbrook, M. R. (1997): The relationship between land use and physicochemistry, food resources and macroinvertebrate 
communities in tributaries of the Taieri River, New Zealand: a hierarchically scaled approach. - Freshwater Biology 37: 177-191.

[48] USEPA (United States Environmental Protection Agency) (2012): National Recommended Water Quality Criteria: Aquatic Life. - United States Environmental Protection Agency, Washington, http://water.epa.gov/scitech/swguidance/standards/criteria/current/index.cfm (accessed 10 March, 2020).

[49] Vannotte, R. L., Minshall, G. W., Cummins, K. W., Sedell, J. R., Cushing, C. E. (1980): The river continuum concept. - Canadian Journal of Fisheries and Aquatic Sciences 37: 130-137.

[50] Zhang, Y., Wang, B., Han, M., Wang, L. (2012): Relationships between the seasonal variations of macroinvertebrates, and land-uses for biomonitoring in the Xitiaoxi River watershed, China. - International Review of Hydrobiology 97: 184-199.

[51] Zhang, Z. Y., Abuduwaili, J., Jiang, F. Q. (2015): Sources, Pollution statue and potential ecological risk of heavy metals in surface sediments of Aibi Lake. - Northwest China Environmental Science 36(2): 490-496.

\section{APPENDIX}

\section{Results of analysis of variance (ANOVA) for sites}

Table A1. Collector-filterers

\begin{tabular}{c|c|c|c|c|c}
\hline & SS & df & MS & F & p \\
\hline Intercept & 1878786 & 1 & 1878786 & 21.6258 & 0.00014 \\
"Site" & 2023574 & 6 & 337262 & 3.88207 & 0.00918 \\
Error & 1824415 & 21 & 86877 & & \\
\hline
\end{tabular}

Table A2. Post-hoc analysis of the collector-filterers

\begin{tabular}{c|c|c|c|c|c|c|c|c}
\hline & Var1 & $\{\mathbf{1}\}$ & $\{\mathbf{2}\}$ & $\{\mathbf{3}\}$ & $\{\mathbf{4}\}$ & $\{\mathbf{5}\}$ & $\{\mathbf{6}\}$ & $\{\mathbf{7}\}$ \\
\hline 1 & S1 & & 0.919330 & 0.7064 & 0.59351 & 0.44503 & 0.69865 & 0.55829 \\
2 & S2 & 0.91933 & & 0.9992 & 0.99440 & 0.06773 & 0.99905 & 0.99116 \\
3 & S3 & 0.70639 & 0.999194 & & 0.99999 & 0.02610 & 1.00000 & 0.9999 \\
4 & S4 & 0.59351 & 0.994395 & 0.999 & & 0.01737 & 0.99999 & 1.0000 \\
5 & S5 & 0.44503 & 0.067731 & 0.026 & 0.01737 & & 0.02537 & 0.01531 \\
6 & S6 & 0.69865 & 0.999053 & 1.000 & 0.99999 & 0.02537 & & 0.99998 \\
7 & S7 & 0.55830 & 0.991155 & 0.999 & 1.00000 & 0.01531 & 0.99998 & \\
\hline
\end{tabular}

Table A3. Collector-gatherers

\begin{tabular}{c|c|c|c|c|c}
\hline & SS & df & MS & F & p \\
\hline Intercept & 1198958 & 1 & 1198958 & 27.38833 & 0.000003 \\
Site & 475145 & 6 & 79191 & 1.80899 & 0.116774 \\
Error & 2145035 & 49 & 43776 & & \\
\hline
\end{tabular}


Table A4. Predators

\begin{tabular}{c|c|c|c|c|c}
\hline & SS & df & MS & F & p \\
\hline Intercept & 14088.0 & 1 & 14088.0 & 19.2434 & 0.00003 \\
Site & 4000.20 & 6 & 666.70 & 0.91067 & 0.49099 \\
Error & 66620.8 & 91 & 732.10 & & \\
\hline
\end{tabular}

Table A5. Scrapers

\begin{tabular}{c|c|c|c|c|c}
\hline & SS & df & MS & F & p \\
\hline Intercept & 95238.1 & 1 & 95238.1 & 6.89483 & 0.01274 \\
Site & 47219.6 & 6 & 7869.93 & 0.56975 & 0.75150 \\
Error & 483454 & 35 & 13812.9 & & \\
\hline
\end{tabular}

Table A6. Shredders

\begin{tabular}{c|c|c|c|c|c}
\hline & SS & df & MS & F & p \\
\hline Intercept & 7581.00 & 1 & 7581.00 & 1.74152 & 0.20812 \\
site & 25782.67 & 6 & 4297.111 & 0.987139 & 0.470084 \\
Error & 60943.3 & 14 & 4353.1 & & \\
\hline
\end{tabular}

\section{ANOVA for seasons}

Table A7. Collector-filterers

\begin{tabular}{c|c|c|c|c|c}
\hline & SS & df & MS & F & p \\
\hline Intercept & 3287876 & 1 & 3287876 & 11.79258 & 0.004949 \\
Season & 1585194 & 3 & 528398 & 1.89520 & 0.184258 \\
Error & 3345706 & 12 & 278809 & & \\
\hline
\end{tabular}

Table A8. Collector-gatherers

\begin{tabular}{c|c|c|c|c|c}
\hline & SS & df & MS & F & p \\
\hline Intercept & 2098176 & 1 & 2098176 & 13.41930 & 0.001028 \\
Season & 1441322 & 3 & 480441 & 3.07275 & 0.043881 \\
Error & 4377942 & 28 & 156355 & & \\
\hline
\end{tabular}

Table A9. Post-hoc of collector-gatherers

\begin{tabular}{c|c|c|c|c|c}
\hline & Season & $\{\mathbf{1}\}$ & $\{\mathbf{2}\}$ & $\{\mathbf{3}\}$ & $\{\mathbf{4}\}$ \\
\hline 1 & $\mathrm{~A}$ & & 0.933996 & 0.855422 & 0.241845 \\
2 & $\mathrm{Sp}$ & 0.933996 & & 0.996930 & 0.079585 \\
3 & $\mathrm{Su}$ & 0.855422 & 0.996930 & & 0.048130 \\
4 & $\mathrm{~W}$ & 0.241845 & 0.079585 & 0.048130 & \\
\hline
\end{tabular}


Table A10. Predators

\begin{tabular}{c|c|c|c|c|c}
\hline & SS & df & MS & F & p \\
\hline Intercept & 24654.02 & 1 & 24654.02 & 15.18067 & 0.000281 \\
Season & 7822.91 & 3 & 2607.64 & 1.60565 & 0.199266 \\
Error & 84450.07 & 52 & 1624.04 & & \\
\hline
\end{tabular}

Table A11. Scrapers

\begin{tabular}{c|c|c|c|c|c}
\hline & SS & df & MS & F & p \\
\hline Intercept & 166666.7 & 1 & 166666.7 & 6.382639 & 0.020068 \\
Season & 15363.3 & 3 & 5121.1 & 0.196117 & 0.897798 \\
Error & 522250.0 & 20 & 26112.5 & & \\
\hline
\end{tabular}

Table A12. Shredders

\begin{tabular}{c|c|c|c|c|c}
\hline & SS & df & MS & F & p \\
\hline Intercept & 13534.08 & 1 & 13534.08 & 3.294568 & 0.107053 \\
Season & 5044.92 & 3 & 1681.64 & 0.409357 & 0.750719 \\
Error & 32864.00 & 8 & 4108.00 & & \\
\hline
\end{tabular}

